ROCZNIK ADMINISTRACJI PUBLICZNEJ 2020 (6)

ARTYKUŁY / ARTICLES

Zarządzanie i ekonomia w administracji publicznej Management and economics in public administration

\title{
Funkcjonowanie administracji publicznej w sytuacji kryzysu spowodowanego czynnikami zewnętrznymi - studium przypadku COVID-19
}

1. Wstęp

Pandemia koronawirusa Sars - CoV-2, która powoduje chorobę określoną mianem COVID-19, skutkuje obecnie poważnymi zmianami w życiu społecznym i gospodarczym państw całego świata. Ich rządy i administracja publiczna stanęły przed koniecznością podjęcia określonych działań. Część spośród nich przedsięwzięła szeroko zakrojone środki służące bezpieczeństwu obywateli (Polska), inne zrobiły to z opóźnieniem (np. Wielka Brytania, Francja), a jeszcze inne nie podjęły żadnych, za wyjątkiem informacyjnych (np. Szwecja). Rozmaicie kształtowała się również komunikacja pomiędzy przywódcami państw, ich rządami, a także pomiędzy władzami a obywatelami odnośnie podejścia do pandemii (przykładowo we Francji prezydent uznał wirusa za wroga) ${ }^{2}$. To zróżnicowanie wynika zarówno z kwestii stopnia uświadomienia sobie przez polityków wagi zagrożenia dla obywateli, lecz również z pewnego podejścia do roli państwa i jego zaangażowania w różnych sferach życia społeczno-gospodarczego, co z kolei jest powiązane $z$ dominującą doktryną polityczną. Zdaniem ekspertów: kraje z funkcjonujacym sektorem publicznym, który zapewnia wszystkim niezbędne usługi zdrowotne, sa lepiej przygotowane do radzenia sobie z pandemia niż inne, które sprywatyzowały opiekę zdrowotna ${ }^{3}$.

1 Dr Paulina Szyja, Instytut Prawa i Ekonomii, Uniwersytet Pedagogiczny w Krakowie.

2 A. de Dossier, Government crisis communication during the coronavirus crisis: Comparing France, Germany, and the United Kingdom, 21.04 .2020 r., http://www.cso. edu/fiche_actu.asp?actu_id=2570 (dostęp 13.07.2020).

3 L. Meuleman, It Takes More Than Markets: First Governance Lessons from the COVID-19 Pandemic, 7 April 2020, https://sdg.iisd.org/commentary/guest-articles/ it-takes-more-than-markets-first-governance-lessons-from-the-covid-19-pandemic/ (dostęp 13.07.2020). 
Jeśli rozpatrujemy wkład państwa w działania na rzecz walki z COVID-19, to nie możemy pominąć administracji publicznej, jej roli w aspekcie pełnionych funkcji, także sprawności i efektywności.

Obecnie obserwujemy kryzys, który stanowi wyzwanie dla procesu podejmowania decyzji, planowania i organizowania środków materialnych i pozamaterialnych niezbędnych do udzielenia wsparcia obywatelom, wreszcie dla samych struktur instytucjonalnych oraz zasobów ludzkich administracji publicznej.

Celem artykułu jest zdiagnozowanie, w jaki sposób choroba COVID-19 wpłynęła i wpływa ( $w$ dalszym ciągu utrzymuje się bowiem stan pandemii ogłoszony przez Światową Organizację Zdrowia) na funkcjonowanie administracji publicznej w oparciu o analizę podejmowanych działań, implementację dobrych praktyk, w takich obszarach jak: zarządzanie zasobami ludzkimi, obsługa klienta, komunikacja na linii władze krajowe i obywatele.

W niniejszym opracowaniu przyjęto następującą tezę badawczą: $\mathrm{w}$ dobie pandemii COVID-19 mamy do czynienia z wielopłaszczyznowym kryzysem, który skutkuje zmianami w funkcjonowaniu administracji publicznej.

Dodatkowo sformułowano następujące pytania badawcze:

- czy pandemię można uznać za sytuację kryzysową?

- w jaki sposób pandemia wpłynęła i wpływa na funkcjonowanie administracji publicznej?

- w jakich obszarach operacyjnych administracji publicznej były konieczne zmiany związane z reakcją/dostosowaniem się do zaistniałej sytuacji?

- w jakich płaszczyznach działań administracji publicznej są wdrażane dobre praktyki ukierunkowane na jej efektywność i skuteczność w dobie pandemii?

$\mathrm{W}$ artykule podjęto rozważania dotyczące działalności administracji publicznej (bez różnicowania na administrację rządową i samorządową) $\mathrm{w}$ dobie pandemii. Artykuł przygotowano z myślą o zaprezentowaniu dobrych praktyk realizowanych w różnych krajach świata. Takie podejście ma na celu z jednej strony ukazanie powszechności aktywności w omawianym zakresie, a z drugiej ma służyć zaprezentowaniu interesujących przykładów metod i narzędzi efektywnego zarządzania w dobie pandemii, które z kolei mogą stanowić wskazówki dla polskich instytucji publicznych podejmujących określone działania.

\section{Pandemia COVID-19 jako źródło kryzysu}

Słowo „kryzys” ma głównie konotacje negatywne, identyfikowane przede wszystkim z nagłą i niekorzystną zmianą, której efektem jest załamanie. Na-

4 V. Tokakis, P. Polychroniou, G. Boustras, Crisis management in public administration: The three phases model for safety incidents, „Safety Science”, 2019, nr 113, s. 37. 
leży jednak zaznaczyć, że wspomniana zmiana może prowadzić do polepszenia sytuacji. Przy czym, w tym wypadku podkreśla się, że w wyniku dostrzeżenia przyczyn kryzysu i znalezienia sposobu jego przezwyciężenia, można podjąć wysiłki ukierunkowane na stworzenie warunków, które nie dopuszczą do podobnego zdarzenia w przyszłości lub ograniczenia możliwych do wystąpienia skutków takowego. Istotne jest przy tym dostrzeżenie szans, a nie tylko zagrożeń, jakie niesie ze sobą kryzys. Warto odnieść się w tym miejscu do treści „Europejskiego planu naprawy gospodarczej” z 2008 roku, którego wstęp został znamiennie zatytułowany - „Nadszedł czas działań”, a w którym José Manuel Durão Barroso (ówczesny szef Komisji Europejskiej) stwierdził: (...) czasy kryzysu rodza okazje do przyspieszenia tempa zmian i podjęcia reform strukturalnych, które umożliwia w przyszłości sukces $w$ globalnej gospodarce przyszłości. To wielka szansa dla Europy ${ }^{5}$. Następstwem kryzysu na rynkach finansowych jesienią 2007 roku był kryzys gospodarki realnej w kolejnym roku. Wówczas rządy państw stanęły przed koniecznością podjęcia działań związanych z zażegnaniem zaistniałej sytuacji. Istotnym jest fakt, że jednocześnie kraje członkowskie Unii Europejskiej zostały wezwane do wdrożenia rozwiązań, które przyczyniłyby się do kształtowania ram rozwojowych w dłuższej perspektywie czasowej, z uwzględnieniem nie tylko ładu gospodarczego, a także społecznego i środowiskowego.

Przyczyny i konsekwencje tych zjawisk, w zależności od płaszczyzny mogą być rozmaite. Istotne jest jednak zwrócenie uwagi, że mogą one mieć swoje źródło w państwie, jako suwerennym podmiocie stosunków międzynarodowych, w szczególności w rezultacie dysfunkcjonalnej polityki lub polityk realizowanych przez rząd, niejasnym i/lub niesprawiedliwym prawie, braku kontroli przestrzegania litery prawa, zbyt daleko posuniętej ingerencji państwa w procesy społeczno-gospodarcze, czy wreszcie nieefektywnej lub nieprawidłowo zarządzanej administracji publicznej (wadliwy system planowania, organizowania i kontrolowania w instytucjach publicznych).

Państwo (rozumiane jako instytucje, instrumenty i narzędzia) jednak niekoniecznie musi stanowić przyczynę crisis - źródła mogą być inne; zewnętrzne wobec państwa i jego instytucji - mogą jednak negatywnie oddziaływać na nie (Rys. 1).

Wybuch pandemii COVID-19 przyczynił się do poważnych perturbacji zarówno w wymiarze społecznym, jak i gospodarczym. Autorzy publikacji pt.: "COVID-19 and the policy sciences: initial reactions and perspectives", stwierdzili wprost: świat stoi w obliczu kryzysu, który nie ma precedensu w żywej pamięci ${ }^{6}$. Departament Organizacji Narodów Zjednoczonych

5 Komunikat Komisji do Rady Europejskiej, Europejski plan naprawy gospodarczej, Bruksela, dnia 26.11.2008

KOM (2008) 800 wersja ostateczna, s. 3.

6 C.M. Weible, D. Nohrstedt, P. Cairney, D.P. Carter, D.A. Crow, A.P. Durnová, T. Heikkila, K. Ingold, A. McConnell, D. Stone, COVID-19 and the policy sciences: initial reactions and perspectives, „Policy Sciences”, 2020, nr 53, s. 225-241. 
Rycina 1. Czynniki kryzysogenne i ich oddziaływanie na administrację publiczną

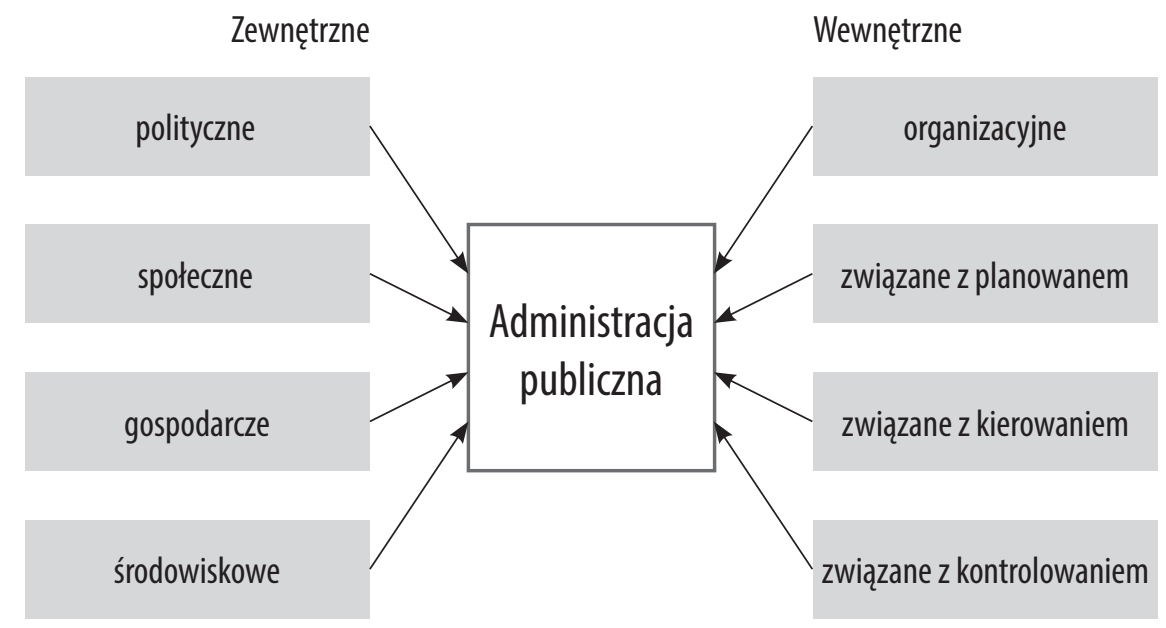

Źródło: opracowanie własne.

w jednym z opracowań używa wprost sformułowania „Kryzys COVID-19 "' W efekcie stopniowego rozprzestrzeniania się choroby w skali globalnej ${ }^{8}$, począwszy od Chin na przełomie 2019 i 2020 roku, a następnie przez kolejne kraje Azji, Europy, Afryki i obu Ameryk, wiosną 2020 roku, zainicjowano szereg działań związanych z zapewnieniem bezpieczeństwa zdrowotnego obywateli. Te podejmowane w Polsce, w pierwszej kolejności dotyczyły przestrzegania środków ostrożności w postaci zachowania dystansu społecznego, a następnie noszenia rękawiczek i maseczek ochronnych. Ze względu na narastającą liczbę zakażeń w innych krajach zamknięto granice. $\mathrm{W}$ trosce o nierozprzestrzenianie się wirusa, zalecono obywatelom pozostawanie w domach. Zamknięto placówki edukacyjne, szkoły wyższe, wprowadzono zdalny system funkcjonowania $\mathrm{w}$ wielu instytucjach administracji publicznej. Ponadto wiele przedsiębiorstw, o ile specyfika ich działalności operacyjnej na to pozwoliła, wprowadziła zdalny tryb pracy. Z kolei szkoły i uczelnie wdrożyły zdalne formy nauczania.

7 UN, DESA: UN/DESA Policy Brief\#61: COVID-19: Embracing digital government during the pandemic and Beyond, https://www.un.org/development/desa/dpad/publication/un-desa-policy-brief-61-covid-19-embracing-digital-government-during-thepandemic-and-beyond/ (dostęp 13.07.2020).

$8 \mathrm{~W}$ dniu 14.07.2020 r. według Światowej Organizacji Zdrowia na świecie zdiagnozowano 12929306 osób zarażonych COVID-19 569738 potwierdzonych przypadków zgonów spowodowanych tą chorobą. WHO: WHO Coronavirus Disease (COVID-19) Dashboard, 14.07.2020 r., https://covid19.who.int/?gclid=EAIaIQobChMIjoGwz9nM6gIVlYBQBh3rnAjNEAAYASAAEgLDTPD_BwE (dostęp 14.07.2020). 
W efekcie pandemii doszło do spowolnienia gospodarczego 9 . Według szacunków EUROSTAT-u wskaźnik Produkt Krajowy Brutto obniżył się o 3,3\% dla całej Unii Europejskiej w pierwszym kwartale 2020 roku w porównaniu do poprzedniego ${ }^{10}$. W raporcie Banku Światowego stwierdzono wprost: większość krajów pogrąży recesja. Przewiduje się, że gospodarki rozwinięte skurcza się o 7\% w 2020 roku. Dla Unii Europejskiej procentowa zmiana PKB w 2020 roku wyniesie -10,1\%, a dla Polski -7,8\% ${ }^{11}$. Najbardziej dotkniętymi branżami okazały się (w chwili pisania tych słów): transportowa, turystyczna, hotelowa, gastronomiczna. Skutki pandemii dotknęły również instytucje kultury: teatry, filharmonie, kina, muzea, galerie sztuki itd. Był to rezultat wprowadzenia w wielu państwach, w tym i w Polsce, stanu epidemii oraz związanych z tym określonych ograniczeń, nakazów i zakazów, które następnie częściowo znoszono. W Polsce ograniczenia zaczęły obowiązywać począwszy od 20 marca 2020. Natomiast ich znoszenie rozpoczęto od 18 maja 2020 roku $^{12}$.

Sytuacja ta nie pozostała bez wpływu na funkcjonowanie instytucji administracji publicznej. Dla klientów różnego rodzaju urzędów publicznych, widocznym znakiem pandemii był ograniczony dostęp do budynków publicznych. Sprawy urzędowe były rozpatrywane w oparciu o rozwiązania komunikacji elektronicznej (poczta elektroniczna, specjalne aplikacje i serwisy internetowe), telefonicznie i z wykorzystaniem tradycyjnej korespondencji pocztowej. Jednak skutki pandemii wpłynęły nie tylko na kwestie związane z obsługą klienta, ale również na organizację funkcjonowania administracji publicznej oraz jej współpracę z innymi podmiotami (przedsiębiorstwami, organizacjami pożytku publicznego). Zagadnienie to będzie przedmiotem analizy w kolejnym podrozdziale. Warto pochylić się nad nim w kontekście pytania zawartego w publikacji autorów: B. Guy Peters, J. Pierre, T. Randma-Liiv, „Czy nowe problemy wymagają nowych rozwiązań?”'13. Można bowiem wprost stwierdzić, że mamy do czynienia

9 Zob. więcej: A. Sieron, Will the COVID-19 pandemic cause a breakdown of the global economy?, 24.04.2020 r., https://uni.wroc.pl/en/will-the-covid-19-pandemiccause-a-breakdown-of-the-global-economy/ (dostęp 14.07.2020).

10 EUROSTAT: newsrelease euroindicators, 81/2020, 15 May 2020, https://ec.europa.eu/eurostat/documents/2995521/10294864/2-15052020-AP-EN.pdf/5a7ea909e708-f3d3-8375-e2510298e1b8 (dostęp 14.07.2020).

11 World Bank Group: Global Economic Prospects, Washington, June 2020, s. 23-24.

12 Należy wymienić m.in. następujące dokumenty: Rozporządzenie Rady Ministrów $z$ dnia 29 maja 2020 r. w sprawie ustanowienia określonych ograniczeń, nakazów i zakazów w związku z wystąpieniem stanu epidemii, Dz. U., 2020, poz. 964; Rozporzadzenie Rady Ministrów z dnia 5 czerwca 2020 r. w sprawie zakazów w ruchu lotniczym, Dz. U., 2020, poz. 1005.

13 B. Guy Peters, J. Pierre, T. Randma-Liiv, Global Financial Crisis, Public Administration and Governance: Do New Problems Require New Solutions?, „Public Organization Review", 2011, nr 11, s. 13-27. 
z wielowymiarowym kryzysem in generali, który wymusił i wciąż wymusza konieczne działania ze strony państwa i administracji publicznej.

\section{Pandemia COVID-19 a działania administracji publicznej w wybranych państwach}

Pandemia koronawirusa Sars CoV-2, tak jak już zostało to wspomniane, dotknęła cały glob. Władze poszczególnych państw i administracja publiczna stanęły przed koniecznością funkcjonowania w nowych warunkach przy jednoczesnym wykonywaniu dotychczasowych, tzw. tradycyjnych zadań, i tych związanych z wymogami zaistniałej sytuacji, tj. reżimu sanitarnego $\mathrm{z}$ jednej strony, a $\mathrm{z}$ drugiej organizowania środków na potrzeby zabezpieczenia społecznego.

Obecnie, tj. w trzecim kwartale trwania pandemii, nie jest jeszcze dostępny szeroki wybór publikacji o charakterze raportów, zaleceń, czy też dobrych praktyk dotyczących funkcjonowania administracji publicznej w dobie pandemii COVID-19. Pomimo to, można zapoznać się już z pierwszymi kompleksowymi opracowaniami w tym zakresie, które wskazują na newralgiczne obszary funkcjonowania administracji publicznej i podejmowane są działania, a także wyzwania i ograniczenia w tym zakresie. Przykładowo we współpracy Organizacji Współpracy Gospodarczej i Rozwoju oraz Unii Europejskiej opublikowano raport pt.: "Public Administration: Responding to the COVID-19 Pandemic", w którym podkreślono trzy istotne obszary z punktu widzenia sprawności państwa i jego instytucji w tym szczególnym okresie, tj.: funkcjonowanie rządu, koordynacja działań, proces podejmowania decyzji. Ponadto wskazano na sposób organizacji usług publicznych i ich jakość oraz zarządzanie zasobami ludzkimi ${ }^{14}$. W odniesieniu do trzech pierwszych kwestii wskazano na wdrażanie i wykorzystywanie technologicznych rozwiązań komunikacyjnych pozwalających na kontakt zdalny w trakcie organizowanych posiedzeń rządu. Co ciekawe niektóre państwa w tym względzie nie posiadały wcześniej odpowiednich ku temu ram prawnych. Podobnie rzecz dotyczy strategii na wypadek wystąpienia pandemii. Wyjątek w tym ostatnim względzie, pośród prezentowanych w raporcie krajów, stanowiły Francja, Niemcy i Wielka Brytania ${ }^{15}$. Warto jednak podkreślić, że w wielu z nich, na potrzeby skutecznego zarządzania, powołano specjalne komisje. Wprowadzono również nowe regulacje prawne dotyczące przykładowo zachowania środków bezpieczeństwa. Niektóre kraje, w tym Estonia, Niemcy, Litwa i Słowenia uruchomiły odpowiednie przepisy odnoszące

14 SIGMA, Public Administration: Responding to the COVID-19 Pandemic, OECD, EU, Paryż 2020.

15 Ibidem, s. 4-5. 
się do sytuacji nadzwyczajnych, które z kolei pozwalają na przyspieszenie i usprawnienie procesów decyzyjnych podczas kryzysu ${ }^{16}$.

W odniesieniu do zarządzania zasobami ludzkimi, państwa zdecydowały się na zastosowanie telepracy w administracji publicznej, tak aby minimalizować narażenie urzędników państwowych na wirusa i zapewnić ciqgłość usług publicznych ${ }^{17}$.

Z kolei w odniesieniu do obywateli i konieczności załatwiania przez nich różnych spraw w urzędach, wdrożono rozwiązania typu: przedłużenie terminu ważności dokumentów, zezwoleń, kontroli technicznych itp.; wydłużono terminy składania deklaracji podatkowych, czy wnoszenia podatków; przyśpieszono wypłaty różnych świadczeń, rozszerzono też zakres niektórych z nich (np. dotyczących opieki nad dziećmi) ${ }^{18}$.

Poza tymi działaniami, warto $\mathrm{w}$ tym miejscu odnieść się do różnego rodzaju praktyk, realizowanych przez administrację publiczną niektórych państw, celem dostrzeżenia rozwiązań, które mimo ich implementacji w dobie kryzysu, mogą stać się skutecznym narzędziem funkcjonowania $\mathrm{w}$ warunkach braku zagrożenia epidemiologicznego. Nie mniej istotne jest zapoznanie się z pewnymi ograniczeniami, czy też negatywnymi aspektami funkcjonowania administracji publicznej, jak również słabościami mechanizmów zarządzania na poziomie operacyjnym, jakie ujawniły się w tym czasie, a które należy stopniowo redukować.

W pierwszym przypadku, wspomniane praktyki można podzielić na trzy płaszczyzny działań: usprawnienia proceduralne, współpraca administracji publicznej z różnymi grupami interesu, komunikacja władz ze społeczeństwem.

Przykłady pierwszej odnoszą się do stopniowego odchodzenia w procedurach formalnych od wymogu elektronicznego podpisu. Skutecznym i prostym rozwiązaniem jest korespondencja mailowa. Nie jest również wymagany podpis elektroniczny. Jeśli występują jakiekolwiek wątpliwości dotyczące tożsamości, urzędnicy proszą o zeskanowane dokumenty $\mathrm{z}$ odręcznym podpisem (Słowenia) ${ }^{19}$. Przy czym rozwiązanie to zastosowano do wąskiego zakresu spraw urzędowych, najczęściej związanych z różnego rodzaju świadczeniami socjalnymi.

Kolejną płaszczyzną kształtowania dobrych praktyk można scharakteryzować przez działania podjęte w Stanach Zjednoczonych, gdzie rząd wystosował wezwanie dla kluczowych interesariuszy branży i ekspertów sztucznej inteligencji do opracowania nowych technik eksploracji tekstu i danych, które mogą pomóc społeczności naukowej w udzieleniu odpowiedzi na pytania związane z COVID-19. Ponadto rozwijana jest, nie tylko

16 Ibidem, s. 6.

17 Ibidem, s. 8.

18 Ibidem, s. 16.

19 Ibidem, s. 16-17. 
w USA, współpraca pomiędzy prywatnymi przedsiębiorstwami a rządowymi agencjami celem przygotowania aplikacji, które pomagają m.in. szpitalom, a umożliwiają one monitorowanie, analizowanie stanu posiadania i pozyskiwanie niezbędnego sprzętu medycznego ${ }^{20}$.

Wydaje się, że stosunkowo najszybciej i najłatwiej wdrażane są praktyki związane z komunikacją pomiędzy władzami państw a obywatelami w zakresie informowania nt. choroby COVID-19. Przykładowo w Buenos Aires za pośrednictwem aplikacji Whatsapp można uzyskać odpowiedzi na pytania dotyczące wirusa. W Bahrajnie, Ministerstwo Zdrowia we współpracy z partnerami Facebook oraz Whatsapp, uruchomiło usługę czatu (w języku arabskim i angielskim), który przekazuje dane nt. rozprzestrzeniania się COVID-19 ${ }^{21}$. Te i inne dobre praktyki w zakresie komunikacji są obecnie gromadzone przez Open Government Partnership z wykorzystaniem specjalnej strony internetowej. Przy czym nie jest to jedyne źródło podobnych informacji.

Bez względu jednak na obszar i cel implementacji dobrych praktyk w dobie COVID-19, niezwykle istotna jest skuteczność podejmowanych działań przez administrację publiczną, a także odpowiedzialność obywateli oraz ich zaufanie do instytucji państwa. Przy czym, w tym ostatnim przypadku, jak pokazuje przykład Singapuru, konieczna jest długoletnia praktyka władz państwa ukierunkowana na wsparcie obywateli na każdej płaszczyźnie życia społeczno-gospodarczego. Nie mniej istotna jest racjonalna polityka rozwojowa oraz wykorzystywanie wszelkich zjawisk kryzysogennych do implementacji rozwiązań, które pozwolą ograniczyć podobne negatywne zdarzenia w przyszłości. Doświadczenie, jakie zdobyły władze Singapuru w trakcie epidemii SARS z 2002 i 2003 roku, pozwoliły na usprawnienie koordynacji działań w sytuacji COVID-1922.

Z kolei zagadnienie negatywnych aspektów funkcjonowania administracji publicznej w dobie pandemii, należy rozpatrywać zarówno w kontekście organizacji zasobów ludzkich administracji publicznej, jak i regulacji prawnych wpływających na sprawność jej funkcjonowania w tym szczególnym okresie czasu. W tym pierwszym zakresie, jak podkreślił w raporcie Bruce Lander - Niezależny Komisarz ds. Walki z Korupcją w Australii - stan pandemii, ale także niestabilność gospodarcza może wpływać negatywnie na urzędników, powodować u nich stres i tym samym obniżać efektywność wykonywanych obowiązków zawodowych. Organizacja pracy zdalnej ogranicza również możliwości kontrolowania podwładnych

20 UN, DESA, UN/DESA Policy Brief\#61: COVID-19: Embracing..., op. cit.

21 Collecting Open Government Approaches to COVID-19, https://www.opengovpartnership.org/collecting-open-government-approaches-to-covid-19/ (dostęp 13.07.2020).

22 J.J. Woo, Policy capacity and Singapore's response to the COVID-19 pandemic, „Policy and Society”, 2020, Vol. 39, Issue 3, https://www.tandfonline.com/doi/full/10.1 080/14494035.2020.1783789 (dostęp 14.07.2020). 
przez przełożonych. Kierownicy są zatem zobowiązani do utrzymywania stałego kontaktu $\mathrm{z}$ urzędnikami, tak aby oni mieli również poczucie „łączności" z daną instytucją ${ }^{23}$. Kolejna kwestia dotyczy technicznych rozwiązań komunikacyjnych, a właściwie zabezpieczenia ich przed dostępem dla nieuprawnionych osób poprzez: urządzenia i systemy zabezpieczone indywidualnym hasłem, zabezpieczenia antywirusowe, zasady gromadzenia i przechowywania informacji ${ }^{24}$. Natomiast w drugim przypadku rzecz dotyczy wprowadzenia przepisów prawnych, związanych z sytuacją kryzysową - jak najsprawniej i najszybciej. Istotne jest bowiem stworzenie odpowiednich warunków, które z jednej strony pozwolą na szybką reakcję i działania odpowiednich służb w zakresie ochrony zdrowia, a z drugiej na udzielenie przykładowo wsparcia finansowego przedsiębiorstwom, tak aby uchronić miejsca pracy.

\section{Administracja publiczna w Polsce w dobie pandemii COVID-19}

Pandemia COVID-19 spowodowała szereg reperkusji dla administracji publicznej w Polsce, co z kolei wpłynęło na konieczność przedsięwzięcia pewnych zmian w następujących płaszczyznach działalności operacyjnej:

- obsługa klienta,

- wewnętrzna organizacja,

- współpraca międzyinstytucjonalna,

- wykonywanie szczególnych zadań powierzonych przez administrację rządową.

Wykaz wybranych zmian we wspomnianych obszarach, polskiej administracji publicznej prezentuje tabela 1 . Ich wybór został podyktowany interesującymi przykładami jakościowo nowych form aktywności podmiotów publicznych, szczególnie w sferze wsparcia bezpośredniego dla przedsiębiorców, jak i organizacji funkcjonowania samych urzędów.

Warto przeanalizować powyższe rozważania szczególnie w kontekście dwóch przykładów, z uwagi na zaangażowane podmioty instytucjonalne. Pierwszy dotyczy nałożenia na powiatowe urzędy pracy obowiązków związanych $\mathrm{z}$ informowaniem oraz przyjmowaniem wniosków o udzielenie niskooprocentowanej pożyczki dla mikroprzedsiębiorców w kwocie 5 tys. $z^{225}$. Drugi dotyczy stworzenia możliwości ubiegania się przez przedsiębior-

23 Hon. Bruce Lander QC, The Independent Commissioner Against Corruption: Public Adminitration in Pandemic: Unique Challenges in the Current Climate, Adelaide 2020, s. 5-6.

24 Ibidem, s. 6.

25 Skorzystaj z niskooprocentowanej pożyczki dla mikroprzedsiębiorców ze środków Funduszu Pracy, https://www.gov.pl/web/gov/skorzystaj-z-niskooprocentowanej-pozyczki-dla-mikroprzedsiebiorcow-ze-srodkow-funduszu-pracy (dostęp 14.07.2020). 
ców o pomoc finansową za pośrednictwem Polskiego Funduszu Rozwoju. Wnioski są składane za pośrednictwem bankowości elektronicznej ${ }^{26}$.

Tabela 1. Wykaz wybranych zmian w organizacji funkcjonowania urzędów administracji publicznej w dobie pandemii COVID-19 w Polsce

\begin{tabular}{|c|c|}
\hline $\begin{array}{l}\text { Główne obszary działalności } \\
\text { urzędów administracji } \\
\text { publicznej powiązanych } \\
\text { z gospodarką oraz urzędów } \\
\text { administracji samorządowej }\end{array}$ & $\begin{array}{l}\text { Wykaz zmian w działalności operacyjnej } \\
\text { administracji publicznej }\end{array}$ \\
\hline \multirow{4}{*}{ 1. obsługa klienta } & $\begin{array}{l}\text { " fizyczne zamknięcie obiektów urzędów dla } \\
\text { klientów; }\end{array}$ \\
\hline & $\begin{array}{l}\text { " wyznaczenie stacjonarnych dyżurów urzęd- } \\
\text { ników w urzędach; }\end{array}$ \\
\hline & $\begin{array}{l}\text { " określenie ram pracy zdalnej urzędników } \\
\text { (czas, zakres obowiązków, wyposażenie } \\
\text { w rozwiązania teleinformatyczne); }\end{array}$ \\
\hline & $\begin{array}{l}\text { " wprowadzenie elektronicznych druków, apli- } \\
\text { kacji (w tym w kooperacji z podmiotami ko- } \\
\text { mercyjnymi, np. banki); }\end{array}$ \\
\hline \multirow{3}{*}{$\begin{array}{l}\text { 2. wewnętrzna organizacja } \\
\text { urzędu }\end{array}$} & " praca zdalna $\mathrm{z}$ domu; \\
\hline & $\begin{array}{l}\text { " organizacja systemu obiegu dokumentów } \\
\text { z wykorzystaniem wewnętrznych rozwiązań } \\
\text { typu intranet; }\end{array}$ \\
\hline & $\begin{array}{l}\text { " utrzymywanie kontaktu kierowników z pod- } \\
\text { władnymi urzędnikami celem kontroli i ko- } \\
\text { ordynacji zadań; }\end{array}$ \\
\hline $\begin{array}{l}\text { 3. współpraca } \\
\text { międzyinstytucjonalna }\end{array}$ & " wymiana informacji pomiędzy instytucjami; \\
\hline \multirow{3}{*}{$\begin{array}{l}\text { 4. wykonywanie szczególnych } \\
\text { zadań powierzonych przez } \\
\text { administrację rządową }\end{array}$} & $\begin{array}{l}\text { " powierzenie nowych obowiązków urzędni- } \\
\text { kom; }\end{array}$ \\
\hline & " szkolenie urzędników; \\
\hline & $\begin{array}{l}\text { stworzenie odpowiednich systemów telein- } \\
\text { formatycznych pozwalających na obsługę } \\
\text { klientów w związku z powierzonymi zada- } \\
\text { niami. }\end{array}$ \\
\hline
\end{tabular}

Źródło: opracowanie własne

Poza wymienionymi w tabeli 1 zmianami, konieczne okazały się określone działania informacyjne oraz organizacyjne, szczególnie w okresie „narodowej kwarantanny”. Zarówno pierwsze, jak i drugie należy dodatkowo scharakteryzować w oparciu o te związane z tradycyjnymi funkcjami poszczególnych urzędów, jak i nowymi w związku z zaistniałą sytuacją.

26 Tarcza Finansowa Polskiego Funduszu Rozwoju dla Małych i Średnich Firm, https://www.gov.pl/web/gov/tarcza-finansowa-polskiego-funduszu-rozwoju-dla-malych-i-srednich-firm (dostęp 14.07.2020). 
Ogólnie kwestie informacyjne obejmowały komunikaty na temat sposobów obsługi klienta, narzędzi komunikacyjnych, udostępnienia formularzy urzędowych drogą elektroniczną, zwiększenia zakresu spraw załatwianych $z$ wykorzystaniem rozwiązań e-administracji. W aspekcie zachowania ostrożności z powodu zagrożenia koronawirusem, urzędy centralne i inne podawały informacje dotyczące postępowania w sytuacji dolegliwości wskazujących na zarażenie wirusem: zachowania dystansu społecznego w miejscach publicznych, noszenia maseczek ochronnych i rękawiczek, stosowania środków dezynfekcyjnych. Na płaszczyźnie organizacyjnej należy wskazać na dwie odmienne sytuacje, tj. w trakcie ścisłej kwarantanny społecznej i stopniowego jej znoszenia; w pierwszym okresie, wiele urzędów zostało zamkniętych i wprowadzano środki ostrożności dla urzędników odbywających dyżury w budynkach administracji publicznej. W kolejnym okresie stopniowo otwierano zamknięte do tej pory placówki i przygotowano środki ochronne dla klientów poszczególnych jednostek. W tym celu rozwieszano informacje na temat zachowania odległości, noszenia maseczek, korzystania ze środków dezynfekcyjnych, dostępnych w urzędach. Konieczne było również wyposażenie punktów obsługi klienta w specjalne osłony chroniące. W płaszczyźnie organizacyjnej, poza zmienionym trybem pracy, zadbano o wyposażenie urzędników w maseczki, rękawiczki i inne środki służące zabezpieczeniu indywidualnemu. Niektóre urzędy gmin zajęły się także pozyskaniem, a następnie dystrybucją wymienionych powyżej środków ochrony indywidualnej wśród mieszkańców.

Wdrażane rozwiązania zyskały podstawy prawne, obejmujące zarówno kwestie ogólne związane z postępowaniem w sytuacji epidemii koronawirusa, jak i z wprowadzaniem określonych ograniczeń, a następnie ich stopniowym znoszeniem, np.:

- Ustawa z dnia 31 marca 2020 r. o zmianie ustawy o szczególnych rozwiqzaniach zwiazanych $z$ zapobieganiem, przeciwdziałaniem i zwalczaniem COVID-19, innych chorób zakaźnych oraz wywołanych nimi sytuacji kryzysowych oraz niektórych innych ustaw, Dz. U., 2020, poz. 568;

- Rozporzadzenie Rady Ministrów z dnia 29 maja 2020 r. w sprawie ustanowienia określonych ograniczeń, nakazów i zakazów w związku z wystapieniem stanu epidemii, Dz. U., 2020, poz. 964;

- Rozporzadzenie Rady Ministrów z dnia 5 czerwca 2020 r. w sprawie zakazów w ruchu lotniczym, Dz. U., 2020, poz. 1005.

- Wprowadzano również przepisy prawne służące udzieleniu wsparcia przedsiębiorstwom w sytuacji pogorszenia ich sytuacji finansowej z powodu epidemii i niemożności utrzymania miejsc pracy, np.:

- Ustawa z dnia 16 kwietnia 2020 r. o szczególnych instrumentach wsparcia w zwiazku z rozprzestrzenianiem się wirusa SARS-CoV-2. Dz. U., 2020 poz. 695 ; 
- Ustawa z dnia 19 czerwca 2020 r. o dopłatach do oprocentowania kredytów bankowych udzielanych przedsiębiorcom dotkniętym skutkami COVID-19 oraz o uproszczonym postępowaniu o zatwierdzenie układu w zwiazku z wystapieniem COVID-19. Dz. U., 2020 poz. 1086.

\section{Wnioski}

Pandemię COVID-19 można bez wątpienia identyfikować z kryzysem, z uwagi na konieczność wprowadzenia kwarantanny społecznej, ograniczeń, nakazów i zakazów służących ograniczeniu rozprzestrzeniania się choroby, a także spowolnienia gospodarczego. Zagrożenie koronawirusem Sars CoV-2 wpłynęło również na funkcjonowanie administracji publicznej, przede wszystkim w sferze organizacji pracy urzędników oraz obsługi klienta. W zaistniałej sytuacji zaczęto powszechniej stosować rozwiązania elektroniczne pozwalające na zdalny kontakt pomiędzy urzędnikami, instytucjami oraz pomiędzy urzędami a klientami. Nie mniej istotnym wyzwaniem było wdrożenie rozwiązań związanych z realizacją tradycyjnych i nowych zadań $w$ dobie pandemii. $W$ tym ostatnim aspekcie rzecz dotyczy wykonywania zadań związanych przykładowo z przyjmowaniem wniosków i udzielania wsparcia finansowego dla przedsiębiorców i pracowników, którzy z powodu koronawirusa stracili pracę.

Kryzys, choć identyfikowany z negatywnymi skutkami, może wbrew pozorom zaowocować pozytywnymi następstwami. Te ostatnie, w ostatnim czasie, w kontekście przedmiotu niniejszego opracowania, są związane $\mathrm{z}$ implementacją dobrych praktyk $\mathrm{w}$ administracji publicznej, ukierunkowane na usprawnienie pracy urzędników, a także poprawę jakości obsługi klientów, czy szybszą wymianę informacji.

Pandemię COVID-19 należy uznać za kryzys, który ma wymiar wielopłaszczyznowy, a jego skutki są poważne. W jej rezultacie zmarło już dziesiątki tysięcy osób. Ponadto zmieniły się realia i warunki życia dla społeczeństw całego globu. Wszystko to nie pozostało bez wpływu na funkcjonowanie państw i ich instytucji. W kontekście zaistniałej sytuacji nasuwa się pytanie, które powinno być przedmiotem dalszych rozważań, a które dotyczy kwestii sposobu zarządzania państwem: czy w rezultacie pandemii należy przyśpieszyć procesy decentralizacji, czy też przeciwnie - centralizacji ${ }^{27}$. Zwolennicy tego ostatniego stanowiska podkreślają, iż reakcja na pandemię jest utrudniona $\mathrm{w}$ sytuacji rozdrobnionych struktur biurokratycznych i odmiennych kultur organizacyjnych instytucji publicznych $^{28}$. Zagadnienie to jest istotne $\mathrm{z}$ uwagi na zapewnienie bezpieczeństwa obywateli i ochrony przed COVID-19.

27 Por. B. Guy Peters, J. Pierre, T. Randma-Liiv, Global Financial Crisis..., op. cit., s. $16-17$.

28 C.M. Weible, D. Nohrstedt, P. Cairney, D.P. Carter, D.A. Crow, A.P. Durnová, T. Heikkila, K. Ingold, A. McConnell, D. Stone: COVID-19..., op. cit., s. 11. 


\section{Bibliografia}

\section{Dokumenty źródłowe}

Komunikat Komisji do rady Europejskiej, Europejski plan naprawy gospodarczej, Bruksela, dnia 26.11.2008

KOM (2008) 800 wersja ostateczna.

Rozporzadzenie Rady Ministrów z dnia 29 maja 2020 r. w sprawie ustanowienia określonych ograniczeń, nakazów i zakazów $w$ związku $z$ wystąpieniem stanu epidemii, Dz. U., 2020, poz. 964.

Rozporzadzenie Rady Ministrów z dnia 5 czerwca 2020 r. w sprawie zakazów w ruchu lotniczym, Dz. U., 2020, poz. 1005.

Ustawa z dnia 16 kwietnia 2020 r. o szczególnych instrumentach wsparcia w związku z rozprzestrzenianiem się wirusa SARS-CoV-2, Dz. U., 2020 poz. 695.

Ustawa z dnia 19 czerwca 2020 r. o dopłatach do oprocentowania kredytów bankowych udzielanych przedsiębiorcom dotkniętym skutkami COVID-19 oraz o uproszczonym postępowaniu o zatwierdzenie układu $w$ związku $z$ wystąpieniem COVID-19, Dz. U., 2020 poz. 1086.

Monografie, artykuły i inne

Collecting Open Government Approaches to COVID-19, https://www.opengovpartnership.org/collecting-open-government-approaches-to-covid-19/ (dostęp 13.07.2020).

de Dossier A., Government crisis communication during the coronavirus crisis: Comparing France, Germany, and the United Kingdom, 21.04 .2020 r., http:// www.cso.edu/fiche_actu.asp?actu_id=2570 (dostęp 13.07.2020).

EUROSTAT, newsrelease euroindicators, 81/2020, 15 May 2020, https://ec.europa. eu/eurostat/documents/2995521/10294864/2-15052020-AP-EN.pdf/5a7ea909-e708-f3d3-8375-e2510298e1b8 (dostęp 14.07.2020).

Meuleman L., It Takes More Than Markets: First Governance Lessons from the COVID-19 Pandemic, 7 April 2020, https://sdg.iisd.org/commentary/guest-articles/it-takes-more-than-markets-first-governance-lessons-from-the-covid-19-pandemic/ (dostęp 13.07.2020).

Peters B. Guy, Pierre J., Randma-Liiv T., Global Financial Crisis, Public Administration and Governance: Do New Problems Require New Solutions?, „Public Organization Review", 2011, nr 11, s. 13-27.

Sieron A., Will the COVID-19 pandemic cause a breakdown of the global economy?, 24.04.2020 r., https://uni.wroc.pl/en/will-the-covid-19-pandemic-cause-a-breakdown-of-the-global-economy/ (dostęp 14.07.2020).

SIGMA, Public Administration: Responding to the COVID-19 Pandemic, OECD, EU, Paryż 2020.

Skorzystaj z niskooprocentowanej pożyczki dla mikroprzedsiębiorców ze środków Funduszu Pracy, https://www.gov.pl/web/gov/skorzystaj-z-niskooprocentowanej-pozyczki-dla-mikroprzedsiebiorcow-ze-srodkow-funduszu-pracy (dostęp 14.07.2020).

Tarcza Finansowa Polskiego Funduszu Rozwoju dla Małych i Średnich Firm, https:// www.gov.pl/web/gov/tarcza-finansowa-polskiego-funduszu-rozwoju-dla-malych-i-srednich-firm (dostęp 14.07.2020). 
UN, DESA: UN/DESA Policy Brief \#61: COVID-1,: Embracing digital government during the pandemic and Beyond, https://www.un.org/development/desa/ $\mathrm{dpad} /$ publication/un-desa-policy-brief-61-covid-19-embracing-digital-government-during-the-pandemic-and-beyond/ (dostęp 13.07.2020).

WHO: WHO Coronavirus Disease (COVID-19) Dashboard, https://covid19. who.int/?gclid=EAIaIQobChMIjoGwz9nM6gIVlYBQBh3rnAjNEAAYASAAEgLDTPD_BwE (dostęp 14.07.2020).

Tokakis V., Polychroniou P., Boustras G., Crisis management in public administration: The three phases model for safety incidents, „Safety Science”, 2019, nr 113, s. 37-43.

World Bank Group: Global Economic Prospects, Washington, June 2020.

Weible C.M., Nohrstedt D., Cairney P., Carter D.P., Crow D. A., Durnová A.P., Heikkila T., Ingold K., McConnell A., Stone D., COVID-19 and the policy sciences: initial reactions and perspectives, „Policy Sciences”, 2020, nr 53, s. 225-241.

Woo J. J., Policy capacity and Singapore's response to the COVID-19 pandemic, „Policy and Society", 2020, Vol. 39, Issue 3, https://www.tandfonline.com/doi/full/ 10.1080/14494035.2020.1783789 (dostęp 14.07.2020).

Żelazowska-Przewłoka A., Kryzys jako element sytuacji gospodarczej, Wyższa Szkoła Biznesu i Przedsiębiorczości w Ostrowcu Świętokrzyskim, Ostrowiec Świętokrzyski 2014.

Abstract

Pandemia koronawirusa Sars - CoV-2 spowodowała poważne zmiany w funkcjonowaniu państw i ich społeczności na całym świecie. Obserwujemy konsekwencje rozprzestrzeniania się choroby, która nie zna granic. Eksperci mówią i piszą o kryzysie, którego skutki dotyczą różnych sfer życia społeczno-gospodarczego. Rządy wielu państw przy wsparciu administracji publicznej podjęły szereg działań związanych z zapewnieniem bezpieczeństwa obywateli, ale również ciągłości funkcjonowania państwa oraz ograniczenia skutków możliwego spowolnienia gospodarczego. Celem artykułu jest zdiagnozowanie, w jaki sposób choroba COVID-19 wpłynęła i wpływa (w dalszym ciągu utrzymuje się bowiem stan pandemii ogłoszony przez Światową Organizację Zdrowia) na funkcjonowanie administracji publicznej w oparciu o analizę podejmowanych działań, implementację dobrych praktyk, w takich obszarach jak: zarządzanie zasobami ludzkimi, obsługa klienta, komunikacja na linii władze krajowe i obywatele.

Słowa kluczowe: administracja publiczna, kryzys, pandemia

\section{The Functioning of Public Administration in a Crisis Situation Caused by External Factors: a COVID 19 Case Study}

The Sars-CoV-2 coronavirus pandemic has caused major changes to the functioning of countries and their communities around the world. We observe the consequences of the spread of a disease which knows no boundaries. Experts talk and write about the crisis, the effects of which affect various spheres of socio-economic life. Governments of many countries, with the support of public administration, have taken a number of activities related to ensuring the safety of citizens, but also the continuity of the state's functioning and reducing the effects of a possible economic slowdown. The goal of the paper is to analyse how the Sars-CoV-2 coronavirus has influenced and still influences 
public administration, taking into account a wide selection of activities, good practices in the areas of human resource management, customer service, as well as communication between national authorities and citizens.

Keywords: public administration, crisis, pandemic 